\title{
CINNARIZINE IN THE TREATMENT OF CHRONIC ASTHMA
}

\author{
M.B. EMANUEL, J.A. CHAMBERLAIN, S. WHITING \& B.G. RIGDEN \\ Centre for Medical Research, The University of Sussex, Sussex BN1 9RF
}

\author{
A.H. CRAVEN \\ Division of Mathematics, The University of Sussex, Sussex BN1 9RF
}

1 Cinnarizine, an inhibitor of calcium ion transport across smooth muscle cell membrane, has been shown to exert an anti-asthmatic effect in patients with chronic asthma.

2 It is postulated that antagonism to calcium ion transport across the mast cell membrane may cause the compound to have a pharmacological effect similar to sodium cromoglycate.

3 Cinnarizine is orally active and its therapeutic effect is demonstrated in a double-blind, cross-over, placebo controlled study.

4 Patient benefit was shown by a significant improvement in peak flow rate. A non-significant trend towards a reduction in symptomatic bronchodilator usage and a decrease in asthma symptom score was also shown.

5 It is concluded that cinnarizine could well prove to be the first of a new family of anti-asthmatic drugs offering a protective effect when taken systemically.

\section{Introduction}

Since the introduction of the topical anti-asthmatic drug sodium cromoglycate (Altounyan, 1967), there has been a marked interest in the development of orally active 'anti-allergic' types of anti-asthmatic drugs.

Cox (1967) demonstrated that sodium cromoglycate was an effective inhibitor of mast cell degranulation. It is known that calcium ions are required for mast cell degranulation induced by compound $48 / 80$ or antigen (Högberg \& Uvnäs, 1960; Saeki, 1964) and it has been suggested that sodium cromoglycate acts by inhibiting the passage of calcium ions across the pulmonary mast cell membrane (Orr, Hall \& Allison, 1972). Contractile microfilaments formed of actinomysin probably play an important role in the selective release process with the transmembrane passage of calcium ions acting as the trigger to microfilament contraction (Orr, 1973). Foreman \& Garland (1976) argue that compounds which prevent or reduce mast cell degranulation may act by preventing or reducing calcium ion transport across the membrane by raising intracellular levels of cyclic AMP. This mechanism would result in the prevention of induced myofibril contraction, hence cell degranulation and the subsequent release of the mediators implicated in bronchial asthma. In support of this theory, Orange, Kaliner \& Austen (1971) have shown that agents capable of increasing intracellular levels of cyclic AMP inhibit IgE mediated mast cell degranulation.

Cinnarizine ((E)-1(diphenylmethyl)-4-(3 phenyl-2propenyl) piperazine) is a compound known to be an antagonist to calcium transport (Emanuel \& Will, 1977). Also, cinnarizine is a classical $H_{1}$ histamine antagonist (Siegler, Bodi, Gershenfeld, Brown, Ducanes \& Nodine, 1962; Zolov, 1961). Aviado (personal communication, 1975) demonstrated that cinnarizine would block bronchospasm induced by antigen-antibody reaction in rats sensitized to Nippostrongyloides. He noted that both sodium cromoglycate and corticosteroids exert such a protective reaction but anti-histamines do not. Therefore, the protective effect of cinnarizine seemed likely to be related to its effect on calcium transport rather than its anti-histaminic action.

In view of the known pharmacological action of the compound and the reported anti-allergic activity, it seemed possible that cinnarizine and its analogues might represent a new class of anti-allergic (anti-mast cell active) drugs. It is hypothesized that these might be related to cromoglycate pharmacologically, having a common mode of action, i.e. prevention of calcium ion induced mast cell myofibril contraction and subsequent cell degranulation. However, cinnarizine is not related chemically to the cromoglycate class of compounds. Finally, cinnarizine is known to be orally 
active: it has been used for its non-asthmatic applications for a number of years and is possessed of a good safety record (Emanuel \& Will, 1977).

\section{Methods}

\section{Patients}

Patients were twelve chronic asthmatics attending a chest clinic. The characteristics of the patients including their actual and predicted peak expiratory flow rates (Leiner, Abramowitz, Small, Stenby \& Lewis, 1963) are shown in Table 1.

No selection was made on the basis of asthmatic aetiology (e.g. allergic history) but, in order to reduce the bronchitic component, all cigarette smokers or patients who had smoked regularly within the last two years were excluded.

Additionally, those entered were considered to represent clinical problem patients-all were on maintenance systemic corticosteroids or had been so within the last year. Each patient had been steroiddose-titrated down to a minimal acceptable level of residual symptoms before the study.

\section{Design}

The study consisted of three parts. Phase I (1 week) was single-blind and all patients were treated with a placebo capsule identical in appearance and taste to cinnarizine $75 \mathrm{mg}$ capsules. Phases II and III (each of 3 weeks' duration) formed a double-blind cross-over study. In phase II patients were randomly allocated to active (cinnarizine, $1 \times 75 \mathrm{mg}$ capsule three times daily) or placebo therapy. In phase III those patients on active drug were crossed over to placebo and vice versa. The objective of phase I was to familiarize patients with assessment techniques (see below) and phases II and III constituted the main double-blind comparative study. The design was approved by the hospital ethical committee.

\section{Assessment methods}

As asthma is a highly variable disease (Scadding, 1977) not only on a day-to-day basis but also from hour-to-hour, it was decided to use a simple lung function test that could be performed frequently by the patients themselves rather than use a test suitable only for clinic visits. Chai, Purcell, Brady \& Falliers (1968) and Saunders (1975) have demonstrated the value of frequent peak expiratory flow measurements in the assessment of asthma using the Wright Peak Flow Meter (Wright \& McKerrow, 1959). It was decided, therefore, to use peak expiratory flow rate, measured three times a day by the patients themselves, as the main assessment monitor for the study. Peak flow gauges (manufactured by Ferraris Engineering) were used in this study as these are much less expensive than the Peak Flow Meter and are also lighter for the patient to carry. A comparison of the gauge and meter (Bhoomkar, Davies, Gear \& Hills, 1975) has demonstrated good correlation between the two instruments. A gauge which was calibrated by the manufacturers before and after the study was supplied to each patient. No significant change in calibration was noted.

Patients were required to record the best of two blows on each occasion and this was noted on the patient record form shown in Figure 1.

In addition the patient was asked to record an 'asthma score' on a visual analogue linear scale similar to that which has been widely used for the

Table 1 Clinical details of asthmatics entering study

\begin{tabular}{|c|c|c|c|c|c|c|c|}
\hline $\begin{array}{l}\text { Patient } \\
\text { number }\end{array}$ & Sex & $\begin{array}{c}\text { Age } \\
\text { (years) }\end{array}$ & $\begin{array}{c}\text { Asthma } \\
\text { duration } \\
\text { (years) }\end{array}$ & $\begin{array}{c}\text { Pre-trial } \\
\text { systemic } \\
\text { steroid } \\
\text { dosage } \\
\text { (mg/day) }\end{array}$ & $\begin{array}{c}\text { Predicted } \\
\text { PEFR } \\
\text { (I/min) }\end{array}$ & $\begin{array}{c}\text { PEFR } \\
\text { pre-trial } \\
\text { clinic } \\
\text { visit } \\
\text { (I/min) }\end{array}$ & $\begin{array}{c}\% \text { actual } \\
\text { to predicted } \\
\text { PEFR }\end{array}$ \\
\hline $\begin{array}{r}1 \\
2 \\
3 \\
4 \\
5 \\
6 \\
7 \\
8 \\
9 \\
10 \\
11 \\
12 \\
\text { Mean }\end{array}$ & $\begin{array}{c}M \\
M \\
M \\
M \\
F \\
F \\
F \\
F \\
F \\
M \\
F \\
F \\
-\end{array}$ & $\begin{array}{l}61 \\
40 \\
60 \\
46 \\
46 \\
52 \\
39 \\
29 \\
51 \\
30 \\
58 \\
59 \\
48\end{array}$ & $\begin{array}{r}24 \\
13 \\
32 \\
8 \\
31 \\
47 \\
32 \\
15 \\
30 \\
19 \\
57 \\
52 \\
30\end{array}$ & $\begin{array}{c}10 \\
2.5 \\
0 \\
4 \\
5 \\
5 \\
10 \\
0 \\
8 \\
8 \\
5 \\
5 \\
5.2\end{array}$ & $\begin{array}{l}540 \\
604 \\
542 \\
571 \\
422 \\
402 \\
434 \\
428 \\
420 \\
596 \\
389 \\
401 \\
479\end{array}$ & $\begin{array}{l}245 \\
390 \\
420 \\
260 \\
270 \\
205 \\
280 \\
140 \\
175 \\
340 \\
240 \\
145 \\
259\end{array}$ & $\begin{array}{l}45 \\
65 \\
77 \\
46 \\
64 \\
51 \\
65 \\
33 \\
42 \\
57 \\
62 \\
36 \\
54\end{array}$ \\
\hline
\end{tabular}




\section{TO THE PATIENT}

1. Please take

2. Please measure your flow score 3 times daily (a) $5-10$ mins after getting out of bed in the morning (b) 5.10 mins after getting home from work or approx $6.30 \mathrm{pm}$. (c) 5.10 mins before going to bed at night.

3. Fill in usage of your HONESTLY*

4. Mark how you felt during the day on the asthma score line. Mark position with arrow.

5. Record other comments - especially non-asthmatic complaints.

\begin{tabular}{|c|c|c|c|c|c|c|c|c|c|}
\hline DAY & $\begin{array}{l}\text { The best } \\
\text { I ever am }\end{array}$ & $\begin{array}{l}\text { The worst } \\
\text { l ever am }\end{array}$ & $\begin{array}{r}\text { FIC } \\
\text { No.1 }\end{array}$ & $\begin{array}{l}\text { ow Scc } \\
\text { No.2 }\end{array}$ & $\begin{array}{l}\text { ore } \\
\text { No.3 }\end{array}$ & $\begin{array}{r}\text { Bronc } \\
\text { dilat } \\
\text { usa } \\
\text { Day } \\
\end{array}$ & $\begin{array}{l}\text { cho- } \\
\text { tor } \\
\text { ge } \\
\text { Night } \\
\text { in } \\
\text { bed }\end{array}$ & $\begin{array}{c}\text { Other } \\
\text { Medicine }\end{array}$ & $\begin{array}{c}\text { Other } \\
\text { comments }\end{array}$ \\
\hline 1 & $\leftarrow$ & $\longrightarrow$ & & & & & & & \\
\hline 2 & $\leftarrow$ & $\longrightarrow$ & & & & & & & \\
\hline 3 & $\longleftarrow$ & $\longrightarrow$ & & & & & & & \\
\hline 4 & $\longleftarrow$ & $\longrightarrow$ & & & & & & & \\
\hline 5 & $\longleftarrow$ & $\longrightarrow$ & & & & & & & \\
\hline 6 & $\longleftarrow$ & $\longrightarrow$ & & & & & & & \\
\hline 7 & $\leftarrow$ & $\rightarrow$ & & & & & & & \\
\hline
\end{tabular}

PATIENT'S COMMENTS:

PHYSICIAN'S COMMENTS:

"Physician to fill in name of bronchodilator aerosol used

Figure 1 Patient record form.

measurement of pain (Huskisson, 1974). The requirement for symptomatic aerosol bronchodilator was noted daily. Patients were asked to keep their level of other therapy (systemic and inhaled steroids, cromoglycate, prophylactic bronchodilator) constant throughout the study-although variations in systemic steroids were occasionally necessary.

\section{Results}

Peak flow values were charted for each patient on a day-to-day basis, a typical set of data being shown in Figure 2. The top daily point represents the best of the day's recorded flow scores and the bottom point the worst.

In the final analysis of results the records of patients 6,8 and 11 were rejected because of non-asthmatic illness during the study (patients 8 and 11) and a large increase in systemic steroid dosage in the placebo phase (patient 6). The results of the remaining nine patients were analysed using the Mann-Whitney U test (Siegel, 1956), the aim being to determine whether the differences in the peak flow measurements between the two phases of the double-blind trial were statistically significant. The daily minimum, maximum and mean were analysed independently and the results are shown in Table 2.

Patients 1 to 4 and 10 (interestingly all the males in the test) showed statistically significant improvement while on cinnarizine. Patient 7 showed a positive response only significant at the $10 \%$ level. In no case was there a significant improvement in favour of the placebo. In the case of patient 9 the Mann-Whitney test applied to the maxima appears to favour the placebo but detailed examination of the record shows 


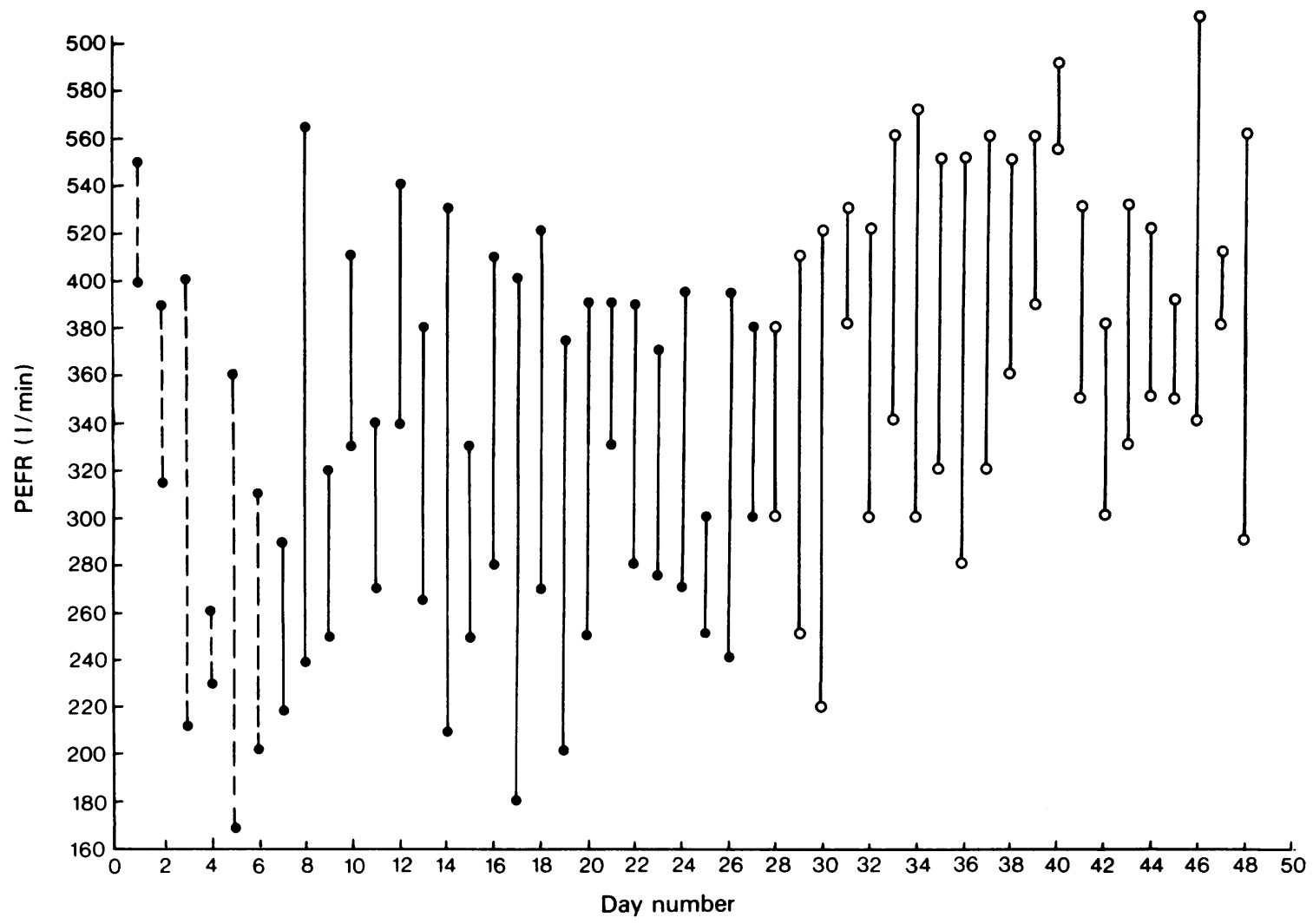

Figure 2 Daily peak flow record. $--\bullet$ placebo run-in; $\mathrm{O}-\mathrm{O}$ active treatment; $\longrightarrow$ placebo treatment.

a trend of continuing improvement during treatment with the active drug (Figure 3 ) which, because of its time-dependent nature, is overlooked by the MannWhitney test since it is there assumed that each reading is an independent observation. Although the patient's performance deteriorated somewhat on entry to the placebo phase the measured peak flow rates were noticeably higher than in the initial phase. Such an indication should not be ignored in the assessment of the drug and this patient is firmly classed as a

Table 2 Statistical analysis of peak flow data

\begin{tabular}{|c|c|c|c|c|c|c|c|}
\hline \multirow{2}{*}{$\begin{array}{l}\text { Patient } \\
\text { number }\end{array}$} & \multirow[b]{2}{*}{ Sex } & \multicolumn{2}{|c|}{ Minimum } & \multicolumn{2}{|c|}{ Maximum } & \multicolumn{2}{|c|}{ Mean } \\
\hline & & $U$ & Significance & $U$ & Significance & $U$ & Significance \\
\hline 1 & $\mathbf{M}$ & 3.98 & $\because *$ & 3.75 & $\cdots$ & 4.39 & $* *$ \\
\hline 2 & $M$ & 2.36 & $\bullet$ & 3.80 & $* * *$ & 3.87 & $\# *$ \\
\hline 3 & $M$ & 4.13 & $\cdots$ & 2.17 & $\bullet$ & 3.90 & *** \\
\hline 4 & $M$ & 4.14 & $\cdots$ & 2.93 & $*$ & 4.08 & $* *$ \\
\hline 5 & $\mathbf{F}$ & -1.05 & 0 & -0.58 & 0 & -0.97 & 0 \\
\hline 7 & $\mathbf{F}$ & 1.85 & 0 & 0.36 & 0 & 1.36 & 0 \\
\hline 9 & $\mathbf{F}$ & -0.23 & 0 & -2.10 & see text & -1.39 & 0 \\
\hline 10 & $M$ & 2.46 & 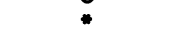 & 3.35 & **** & 3.27 & $*$ \\
\hline 12 & $\mathbf{F}$ & 0.57 & 0 & 0.02 & 0 & 0.06 & 0 \\
\hline
\end{tabular}

$U: A$ positive value of $U$ shows a trend in favour of active compound.

0 : Not statistically significant.

": Improvement significant at 5\%; "*: Improvement significant at 1\%; ***: Improvement significant at $0.1 \%$. 


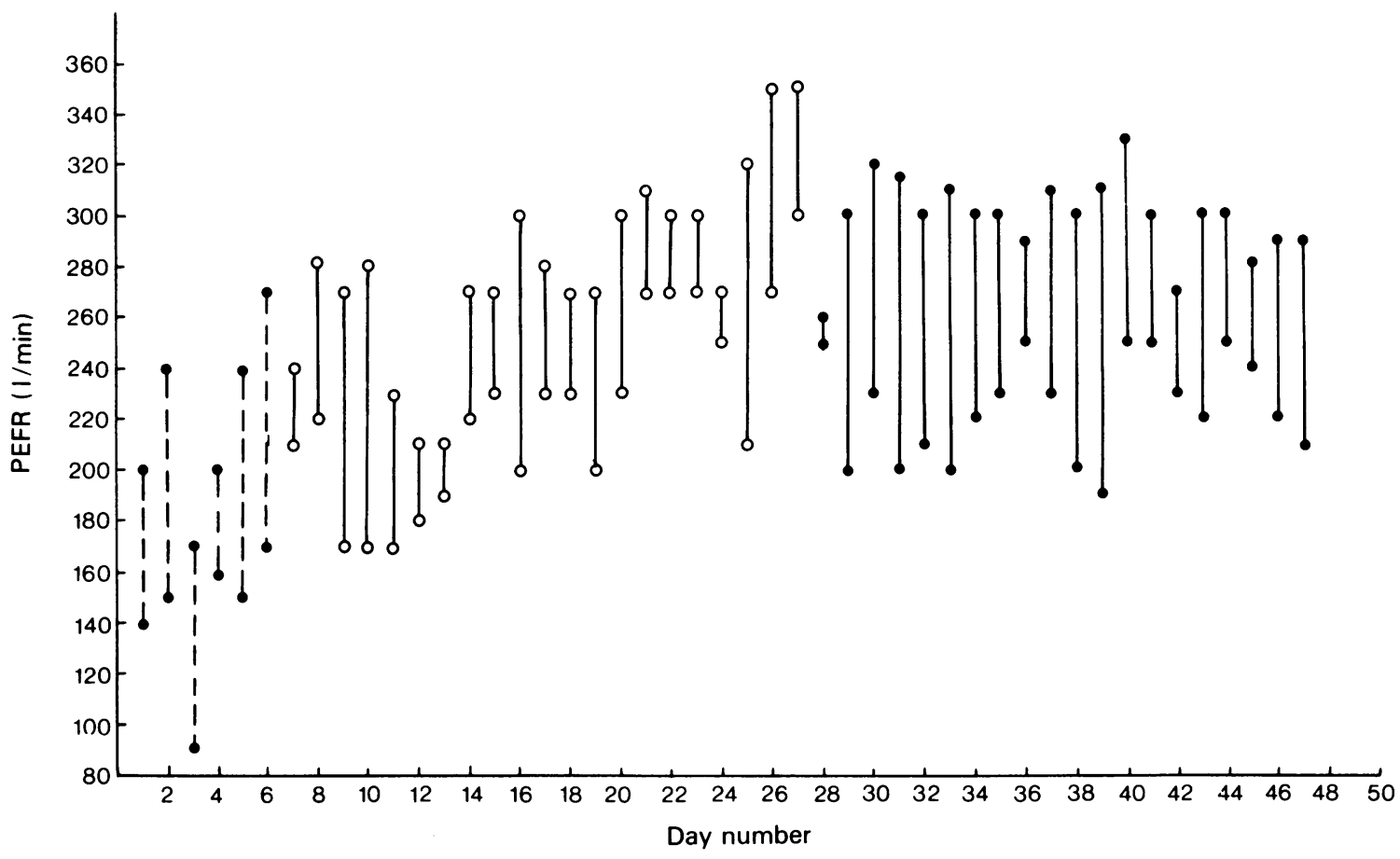

Figure 3 Time-dependent response to active drug. --- placebo run-in; $-\mathrm{O}$ active treatment; placebo treatment.

responder (Figure 3). The response of this patient does indicate that time-dependence is a possible additional factor which must be included in the design of any future trials.

A separate analysis of all peak flow readings showed that $60 \%$ of low readings were morning lows, the other $40 \%$ of lows being distributed almost evenly between afternoon and evening readings.

Additional data used to assess the overall efficacy of cinnarizine therapy are shown in Tables 3 and 4 . Although not significant statistically at $5 \%$ because of the large variances, the results are not without interest.

Table 3 Bronchodilator aerosol usage (when used symptomatically)

\section{Patient number Active phase Placebophase}

$\begin{array}{crr}1 & 58 & 81 \\ 2 & 113 & 131 \\ 3 & 22 & 29 \\ 4 & 59 & 141 \\ 9 & 99 & 80 \\ 10 & 90 & 120 \\ 12 & 9 & 8 \\ \text { Total } & 450 & 590 \\ \text { Mean } & 64 & 84 \\ \text { s.e. mean } & 14 & 19\end{array}$

In five out of seven patients who used a bronchodilator aerosol for symptomatic relief there was less usage when being treated with cinnarizine and as a group there was a $24 \%$ total reduction in aerosol usage.

In five out of nine patients the asthma score was reduced by $20 \%$ or more when taking cinnarizine, in three patients there was no score difference and patient 5 scored better in the placebo phase.

Table 4 Visual analogue asthma score

\begin{tabular}{cccc}
\hline Active & $\begin{array}{c}\text { Placebo } \\
\text { phase } \\
\text { mean }\end{array}$ & $\begin{array}{c}\text { \% reduction } \\
\text { in asthma } \\
\text { score in } \\
\text { active compared } \\
\text { with placebo }\end{array}$ \\
number & mean & mean & \\
1 & 1.8 & 4.9 & 63 \\
2 & 4.9 & 6.1 & 20 \\
3 & 0.5 & 0.8 & 38 \\
4 & 2.1 & 6.7 & 69 \\
5 & 6.8 & 5.2 & -31 \\
7 & 5.7 & 5.8 & 2 \\
9 & 4.5 & 4.3 & -5 \\
10 & 2.2 & 4.5 & 51 \\
12 & 6.0 & 5.4 & -11 \\
Mean & 3.8 & 4.9 & 22 \\
s.e. mean & 0.7 & 0.6 &
\end{tabular}


Overall, patients had a $22 \%$ reduction in asthma score when being treated with cinnarizine.

Although patients were asked to note down side effects as 'other comments' on a daily basis, none were reported.

\section{Discussion}

Because of the marked degree of variability of asthmatic symptoms it is difficult to show the benefit of anti-asthmatic therapy unless it provides symptomatic relief of the acute attack. In this study we attempted to reduce these difficulties by utilizing the day-to-day variability positively as the main assessment criterion.

It was found that patients, given basic explanation, could readily measure their own peak flow rate and record their bronchodilator usage and 'asthma score' daily on the same record card. Our experience suggests that a truer reflection of asthma therapy is gained by measuring lung function simply and often rather than by infrequent measurements of a more elaborate nature. This method has been used on hospitalized patients by Chai et al. (1968) but is rarely used in out-patient studies.

The performance of cinnarizine in this study suggests it is an active anti-asthmatic agent. It has been tested on patients who present problems in management, yet in five out of nine patients improvement on the active drug was such that statistical significance in its favour could be shown in the individual patient. Only two patients seemed not to respond at all to the drug.

Patient benefit was suggested by a decreased trend in asthma symptom score and a reduction in symptomatic broncodilator usage, as well as by a significant measured improvement in lung function. It is particularly encouraging to note the similarity in the trends of the peak flow measurements, the asthma score and bronchodilator usage. In general, those patients with the greatest improvement in lung function showed the greatest improvement in their symptom measurements.

Initially it was felt that, when analysing peak flow scores, the morning reading or daily minimum would have the highest clinical value. Many asthmatics say that they are at their worst early in the morning. It was therefore interesting to attempt to verify this by examining the times of day at which the lowest peak flow rates occurred. Only $60 \%$ of lows were morning readings. Additionally, our analysis of minimum, maximum and mean daily flow rates showed that all three behave similarly, reflecting the clinical state in the same way. It would seem that in future studies it will be desirable to measure flow rate three times daily as in this study and to analyse maxima, minima and means independently. If patient compliance should make that ideal unobtainable, a single early morning reading might be an acceptable compromise.

The study design did not anticipate time-dependent response or carry-over effect from active to placebo phase. Consequently future studies should, if possible, include a placebo wash-out period between treatment with the active drug and the placebo.

A noted and interesting phenomenon is the statistically significant difference in drug response between male and female patients in the study.

All five males showed a marked response. Of the four females analysed two showed an improvement and the other two were classified as non-responders. An explanation for this may lie in the difference in patient characteristics in terms of age of onset and duration of asthma: average duration of asthma in the males was 19 years with a mean age of onset of 28 years, whereas for the females average duration was 36 years with a mean age of onset of 10 years. These findings strongly suggest that, as with sodium cromoglycate (Brogden, Speight \& Avery, 1974), the best results may be expected in those patients with the shortest duration of asthma and hence a greater reversible element in their obstructive airways disease. However, even in the most responsive group, the mean duration of asthma of 19 years is such that a marked degree of irreversibility would be expected. More dramatic results might be expected in younger patients with less well established and less severe asthma.

We thank Mr G.M.E. Williams of the Ferraris Development and Engineering Co. Ltd. for his help in the calibration of the peak flow gauges and Mr G.M. Clarke of The University of Sussex for his advice on statistical methods. We are also grateful to Janssen Pharmaceutical Ltd, Marlow, Buckinghamshire, for provision of clinical trial supplies.

Requests for reprints should be addressed to MBE.

\section{References}

ALTOUNYAN, R.E.C. (1967). Inhibition of experimental asthma by a new compound: disodium cromoglycate, Intal. Acta Allerg., 22, 487.

AVIADO, D.M. (1975). Antiasthmatic action of cinnarizine and flunarizine. Personal communication. Janssen Pharmaceutica, (Beerse, Belgium) Report No. N8670.

BHOOMKAR, A., DAVIES, S., GEAR, M. \& HILLS, E.A. (1975). Comparison of peak flow gauge and peak flow meter. Thorax, 30, 225-227.

BROGDEN, R.N., SPEIGHT, T.M. \& AVERY, G.S. (1974). Sodium cromoglycate (cromolyn sodium): a review of its mode of action, pharmacology, therapeutic efficacy and use. Drugs, 7, 164-272.

CHAI, H., PURCELL, K., BRADY, K. \& FALLIERS, C.L. (1968). Therapeutic and investigational evaluation of asthmatic children. J. Allergy, 41, 23-36. 
COX, J.S.G. (1967). Disodium cromoglycate (FDL 670) (Intal): a specific inhibitor of reaginic antibody-antigen mechanisms. Nature, 216, 1328-1329.

EMANUEL, M.B. \& WILL, J. (1977). Cinnarizine in the treatment of peripheral vascular disease: mechanisms related to its clinical action. Proc. Roy. Soc. Med., 70 (Suppl. 8), 7-12.

FOREMAN, J.C. \& GARLAND, L.G. (1976). Cromoglycate and other anti-allergic drugs: a possible mechanism of action. Br. med. J., 1, 820-821.

HÖGBERG, B. \& UVNÄS, B. (1960). Further observations on the disruption of rat mesentery mast cells caused by compound 48/80, antigen/antibody reaction, Lecithinase A and Decylamine. Acta Physiol. Scand., 48, 133-145. HUSKISSON, E.C. (1974). Measurement of pain. Lancet, ii, 1127-1131.

LEINER, G.C., ABRAMOWITZ, S., SMALL, M.J., STENBY, V.B. \& LEWIS, W.A. (1963). Expiratory peak flow rate (Standard values for normal subjects. Use as a clinical test of ventilatory function). Am. Rev. Resp. Dis., 88, 644-651.

ORANGE, R.P., KALINER, M.A. \& AUSTEN, K.F.(1971). The immunological release of histamine and slow reacting substance of anaphylaxis from human lung. In Biochemistry of the acute allergic reactions. pp. 189-204. Oxford: Blackwell Scientific.
ORR, T.S.C. (1973). Mast cells and allergic asthma. Br. J. Dis. Chest, 67, 87-106.

ORR, T.S.C., HALL, D.E. \& ALLISON, A.C. (1972). Role of contractile microfilaments in the release of histamine from mast cells. Nature, 236, 350-351.

SAEKI, K. (1964). Effects of compound 48/80, chymotrypsin and antiserum on isolated mast cells under aerobic and anaerobic conditions. Jap. J. Pharmac., 14, 375-390.

SAUNDERS, K.B. (1975). The assessment of respiratory function. Br. J. Hosp. Med., 13, 228-238.

SCADDING, J.G. (1977). In Asthma. ed. Clark, T.H.J. \& Godfrey, S. pp. 1-10. London: Chapman and Hall.

SIEGEL, S. (1956). Non-parametric statistics for behavioral sciences, pp. 116-127. McGraw-Hill.

SIEGLER, P.E., BODI, T., GERSHENFELD, M.A., BROWN, E.B., DUCANES, A.D. \& NODINE, J.H. (1962). Human bio-assay of antihistaminic agents. Ann. Allergy, 20, 37-44.

WRIGHT, B.M. \& McKERROW, C.B. (1959). Maximum forced expiratory flow rate as a measure of ventilatory capacity. Br. med. J., 2, 1041-1047.

ZOLOV, B. (1961). Clinical evaluation of cinnarizine (Mitronal) in various allergic disorders. Ann. Allergy, 19, 1290-1294.

(Received February 23, 1978) 